\title{
THE ROLE OF STRUCTURAL ENGAGEMENT IN INTER- RELIGIOUS DIALOGUE: IN THE CASE OF THE INTER- RELIGIOUS CONFLICT IN GPDI SEMANU, GUNUNGKIDUL
}

\author{
Perdana Aysha Puteri ${ }^{\mathrm{a}, 1, *}$ \\ ${ }^{a}$ Universitas Islam Negeri Sultan Thaha Saifuddin, Jambi, 36361, Indonesia \\ ${ }^{1}$ ayshputeri@gmail.com*;
}

ARTICLE INFO

Article history:

Received : 2021-09-09

Revised : 2021-12-22

Accepted : 2021-12-30

Keywords:

Structural Engagement

Conflict

Inter-Religious Relations

\section{ABSTRACT}

The case of expulsion of a pastor at Semanu Gunungkidul GPdI church was resolved through mediation by the regional assistant. The conflict was triggered by the issue of Christianization by the pastor of GPdI Semanu. Today the conflict has ended, but it still leaves prejudice among religious leaders and structural officials in the area. The main data were interviews with those who directly involved in conflict and in efforts to resolve it. They were Muslim and Christian religious leaders, FKUB, sections of local government that were directly dealt with conflict, local communities, and community organizations accompanying the conflict resolution process. The Indonesian government was one of the important factors in the process of conflict and its resolution. The recent research on interfaith conflict and dialogue emphasized the role and influence of grassroots communities.

\section{ABSTRAK}

Kasus pengusiran pendeta di gereja GPdI Semanu Gunungkidul diselesaikan dengan mediasi oleh pendamping wilayah. Konflik tersebut dipicu oleh isu kristenisasi oleh pendeta GPdI Semanu. Hari ini konflik itu telah selesai, namun masih menyisakan prasangka di kalangan tokoh agama dan pejabat structural di daerah tersebut. Data utama tulisan ini adalah wawancara kepada mereka yang terlibat langsung dalam konflik serta dalam usaha penyelesaiannya. Mereka adalah tokoh agama Muslim dan Kristen, FKUB, bagianbagian pemerintah daerah yang terkait langsung dengan urusan konflik tersebut, masyarakat setempat, serta organisasi masyarakat yang mendampingi proses penyelesaian konflik.Tulisan ini ingin melihat bagaimana peran elit agama dan pemerintah yang didukung penuh dalam struktur pemerintahan Indonesia menjadi salah satu yang penting dalam proses terjadinya konflik dan penyelesaiannya. Meski penelitian terakhir tentang konflik dan dialog antar agama menekankan pada peran dan pengaruh masyarakat akar rumput, tulisan ini ingin mengingatkan bahwa peran elit masyarakat juga penting.

\section{Introduction}

In 2014, the Wahid Foundation ranked Yogyakarta province as the second intolerance province in Indonesia, while Gunungkidul regency is the most intolerance in Yogyakarta province. Gunungkidul Describing briefly about Semanu, Semanu is one of districts in Gunungkidul regency. Gunungkidul regency is bounded by Klaten regency and Sukoharjo regency, Central Java 
province at north side; Wonogiri regency, Central Java province at east side; Indonesia ocean at south side; and Bantul regency and Sleman regency, DI Yogyakarta Province at west side. The area of Gunungkidul regency was habited by 722.479 people in 2016 . The poverty of Gunungkidul regency in 2016 was 139.150 people $(19.34 \%)$. Based on the BPSStatistics of Gunungkidul regency, Semanu has 55.268 Muslim members and 597 Christian members with 104 mosques, 12 musholah, and 8 Christian churches (Regency, 2017). The occurred religious conflicts were between Muslim and Christian, such as sealed church off at Widoro, Girisubo; sealed church off at Playen, protesting an Easter celebration at Adiyuswa Sinode; protesting construction of Gua Maria Wahyu, Gedangsari; forcedly sealing a church and priest's expulsion at GPdI Semanu (UI, 2018). This paper will be focused on the curred conflict at Semanu.

The conflict has been occurred Muslim and Christian, in Semanu, Gunungkidul caused priest Agus and his family to be expelled from his house. Muslim's prejudice of Christianization was exist within Muslim surrounding GPdI church, especially when students of a Christian university from Semarang came and teach children of Semanu people (I, 2018; J, 2018; K, 2018; UI, 2018). The prejudice becomes stronger and spreads out to other region than it was heard by Laskar Jihad. Laskar Jihad are residents were executor to solve the Christianization expelling the priest and sealing the church at night. (J, 2018; TH, 2018) In a night, people meet together and propose some demands to the priest to be filled, before he returns to his house and open opens church. According to priest Agus, the meeting is a conspiracy because the meeting was deliberately planned. (A, 2018) The demands were the operational permit of the church like what hospital should have; based on security reasons, the priest should move and rent a house for two years located $8 \mathrm{~km}$ from Semanu and the house become house of worship while the church was closed. After nine months, he and his family return to their house, although the church still could not have a license to worship in. Moreover, Christmas day 2011 celebration could not be held in the church and should move to published $\mathrm{c}$ hall our village office.

During 2012-2014, there is not any impactful action to resolve the problem, until
2015 mediation was done by the government. In that time some NGOs attempt to create meeting space to produce dialogue, nonetheless that effort does not dock the core of the problem. On the 2015, Tomi Harahap as assistant area asked the regent to give authority to resolve the case. After getting the regent's permission, he invite the local authority and leader separately to know what exactly happen on the ground of the issue. Collecting data from some meetings made Tomi be able to straighten the problems that the crucial one of them was local regulation for houses of worship before 2006. Tomi has held the final meeting to mediate some kinds of problems that were arisen by people who caused the expulsion. The final meeting was ended with apologizing from priest Agus and the acceptance from society for the priest and his family. The acceptance was also marked by the return of the priest and his family and the license to use the church accordingly $(\mathrm{K}$, 2018; TH, 2018).

However, the success of mediation was not only occurred by Tomi's effort but also supported a by particular condition, which was shaped by certain efforts of actors and organizations. The actors are the members of Interreligious Harmony Forum (FKUB) of Gunungkidul, head of Churches Partnership Institution (Badan Kerjasama Seluruh Gereja BKSG), the government in the sub-district and district level, and leaders in the grassroots level. While, the involved organizations are National Alliance of Bhineka Tunggal Ika (Aliansi Nasional Bhineka Tunggal Ika (ANBTI)), Interfaith Forum (Forum Lintas Iman) (I, 2018; K, 2018). This paper will show how the actors have their own willingness of interreligious dialogue, but they work separately and partially. I argue that separately structural engagement (emphasizing to the actors) becomes obstacle of inter-religious dialogue. Furthermore, I argue that structural engagement should be power to create the other engagement, such as national engagement, quotidian engagement, and symbolic-imagined engagement.

\section{Literature Review \\ a. Engagement for effective inter- religious dialogue: a theoretical framework \\ Some scholars offer various definitions of} inter-religious dialogue that concerns 
different concern and scope of the dialogue. Beginning from Swidler's definition, that inter-religious dialogue is "...dialogue is a two-way communication between persons who hold significantly differing to learn purpose of learning more truth about that subject from the other person." (Swidler, 2014) Swidler explained more and detail about how communication among people enable to produce wider and more varied understanding about their belief. Swidler analyzed the process and the basis of transformation of understanding from one religion or belief to another. Furthermore, Swidler argued that everyone in the religious community with certain conditions can be involved in the dialogue. Here, I will highlight from Swidler argument that one who is involved in the dialogue is not limited by official representative of a religious community, but certain condition to involve in the dialogue is needed in order to avoid debate. (Swidler, 2014) However, Swidler explained the dialogue clearly and normatively as a basic understanding of common dialogue.

While the definition of Banawiratma's inter-religious dialogue did not clearly explain what dialogue and the scope or form of the dialogue is? Nevertheless Banawiratma has explained the dialogue social reality-based as inter-religious dialogue in order to differentiate it from inter-faith dialogue that is based on something personal. He has detailed the forms of the dialogue based on various contents of the dialogue. Those forms are: dialogue of life, social analysis and contextual ethic reflection, study of religious traditions, inter-religious dialogue: sharing of deep level of faith, inter-religious dialogue: interreligious theology, dialogue of action, intrareligious dialogue. Banawiratma argued that dialogue can be begun from any form else and hence those forms are not gradual order. (Banawiratma, 2010) Furthermore, some division created by Banawiratma encompass some forms of inter-religious engagement in Lattu's term.

Lattu's dissertation try to go beyond common and limited kinds of inter-religious dialogue, which he formulated based on Mollucan cases called as inter-religious engagement. For Lattu existing discussion about inter-religious missed the other dimension of the dialogue. The existing understanding about the dialogue tend to show the dialogue among elites in the formal ways, while the informal form of dialogue, such as dialogue of life and dialogue of action by Banawiratma, has been discussed by some scholars in the limited discussion. (I. Lattu, 2014) Lattu argued that the dialogue could be occurred in four forms of engagement, there are: associational engagement, quotidian engagement, symbolic-imagined engagement, and structural engagement. Associational engagement is connection constructed by sharing the same interests, values, and attitudes among people. The similarities can became or related with anything else, it can be either religious-concern or secular-concern. The secular concern enable to create the tight connection among members of community so that trust will be built to reach even sensitive issue of religion. Quotidian engagement is shaped by everyday life relatedness among people in particular area. Encountering and communication in everyday life will make unless between two persons know each other. However, everyday life connection will go beyond religion and identity, because in social life one will be need the others. Moreover, everyday life engagement in quotidian engagement is also supported by symbolicimagined engagement as the part of relatedness. In social life of a society symbolization of something that related to each of them will be fond and tied them. Based on society's communalities, that they jointly recognize and hold it, people will enable to build trust. (I. Lattu, 2012) While structural engagement is religious exchange and relatedness among religious people that is deliberately created by particular people who have power for the realization of interreligious dialogue.

To explain the scope of structural involvement, I will borrow Weber's terminology in authority theory, namely the legal authority, to understand who people are involved in the structure to differentiate with scope of the other engagement. Weber's argument about legal authority that was explained by Campbell: "Legal authority is based on a belief in the "legality" of patterns and normative rule, where loyalty is given to a legally established impersonal order." (Campbell, 2007) With using Weber's argument, I argue that people who is in the structural engagement have the given power 
by structural system, such as: state, organization, and any structural system that choose people with certain criteria and run the role with certain determined system. Therefore, based on Weber division about the authority, I relate the scope of structural engagement with the capability of certain people to intervene and control the condition and communication between or among interreligious community in particular area (Basri, 2011).

With this, religious community and its dynamic will not be separated from the role of people in structural system. According to Lattu: "Structural engagement within interreligious communities deals mainly with political power/structural interventions in the space of interreligious interaction." (I. Y. Lattu, 2012). In detail for instance, state has religious regulation and law to prevent conflict as well as maintain peace relation between two religious communities or among certain religious communities, and hence government is able to punish or intervene religious community. In sum, those engagement is the process of building trust by using wider and various sources as the modal to create suitable condition of inter-religious dialogue, and in the same time, those engagement is also the process of interreligious its-self.

This paper will focus on the structural engagement that will be measured from interreligious mediation conflicts that were successfully conducted in GPdI, Semanu, Gunungkidul. In additions, the term 'conflict' in this paper means the interaction between two persons or among groups that is occurred in contradiction and incompatible conditions. (Galtung, 1973) Although the interaction between two persons will always find the incompatible condition. Therefore, conflict is an unavoided condition. Furthermore, related to the structural issues, Galtung has divided conflict based on structural and unstructural of actors. The structural is when the conflict come from a party that has no prior interaction, and come to the other region to take the other's thing as a party's interest. In the other side, the unstructural is people who is involved in the conflict based on the nature interaction. (Jeong \& Michael, 2010) In sum, in the case of inter-religious conflict, the occurred conflict is occurred based on the nature interaction among people from different religions or different ideologies of a religion (Kurtz, 2008).

The next one will be examined also to what extent the structural engagement can form an effective dialogue. Because, in previous research conducted by me and my friends entitle "Is Dialogue Satisfactory for Interreligious Relationship?: A Case of Interreligious Conflict in Gunungkidul, DI Yogyakarta", has come to the conclusion that inter-religious dialogue after the conflict in GPdI Semanu did not work, in fact prejudice among the people still exists. (Mubarok, Puteri, Ahsan, \& Siragih, t.t.) The condition was in line with Lattu's argument in his dissertation: "Instead of a push toward fruitful social engagement, the leader-dominated model of interreligious relationship was only able to promote ceasefire." (I. Lattu, 2014) However, mediation, which keeps the priest back and the church can be used accordingly, not based on built trust. In spite, I agree and appreciate that mediation is the fastest and the most effective in solving this GPdI problem, which is one of the reasons is the absence of a religious house permit as a problematic of the implementation of the religious regulation made by state.

\section{Research Methodology}

This research uses descriptive qualitative method. I collected data by conducting direct observations by living in Semanu and indirect observations through electronic news and newspapers. I also collected data by conducting interviews with non-governmental organizations that accompanied the conflict resolution process, Semanu village community leaders, village government, religious leaders (both from Islam and Christianity) who are members of FKUB/Forum Kerukunan Umat Beragama, and several village communities. I analyzed the results of these observations and interviews by using related theories of conflict and religion studies.

\section{Results and Discussion}

a. Separately structural engagement in inter-religious relationship after conflict

Based on a three-day interview, authorities were able to resolve religious conflicts based on state regulations on religious affairs. 
Before the mediation of the assistant area, the dialogue effort was done by FKUB, ANBTI, BKS, and Interfaith Forum separately and not yet able to return the priest to the house. The role of government is important in this case, because the main issue problematized by people who expelled the priest is the issue of church license. To solve the licensing problem, only the government has the authority and is able to resolve licensing issues, because people would not allow priest to return until he fulfill the license. Another issue was the Christianization issue as a fundamental problem that is not resolved by the mediation. The Christianization issue need more involvement from other layers of structural engagement, because the govern structure will not be able to resolve the issue alone.

With this, the GPdI conflict needs to be resolved in two issues, and this paper will address the problem solving of these issues based on structural engagement. As I mentioned earlier, the issue of church license has been solved by the assistant area. With this, the facts show how religious conflict based on legal and regulatory issue can be solved by the government. In this case, the assistant area -with a warrant from Gunungkidul regent- investigates and finds a solution by inviting local leaders and local administrators. The assistant area held convened meetings with the people to clarify the problem, provide a win-win solution to Muslim and Christian parties and show that the expulsion is a crime. The win-win solution in the conflict is the result of communication and negotiation between two or many parties who is involved in the conflict, which is able to please all parties by find the agreement and satisfy certain part of their interest. The winwin solution was to record all unlicensed houses of worship, and it was found that there were many mosques and small mosques that did not have license, so the assistant area recorded and issued permits for all unlicensed houses of worship to prevent religious conflicts which occurred as a result of the problem of licensing houses of worship. In addition, the capacity of assistant area to warn removing parties to stop such acts, which are submitted under the law of it.

After the conflict, some actors have their own initiative on behalf of their organization that governs the programs. In running the program, some actors run cooperation with several parties and not with other parties. For example, when Kris -a vice head of conflict who is a Christian- organized Sekolah Kebhinekaan (Diversity School) in Gunungkidul, he did not cooperate with head of FKUB, Iskanto. In addition, each organization tends to produce their own programs without involving other organizations. I argue that programs involving more actors will be able to involve more people and from a wider audience. In addition, involving more actors will result in sustainable and systematic program, and then the prejudices of Christianization will be gradually erased. With this, it appears that structural involvement is not well established and the trust among certain actors was not yet built.

Trust has not been established among the characters, leading them to deny the role of each other in conflict reconciliation efforts. Tomi as an assistant area assess that the relationship between religions in society Gunungkidul is not healthy, and even including the relationship among figures in FKUB. The disharmony causes some cases arise, or are not resolved properly by certain figures because of the disharmony ( $\mathrm{TH}$, 2018). On the side of FKUB itself the head of FKUB deny the role of NGOs. Furthermore, the disharmony condition occurred between Muslim and NGO, especially ANBTI, Iskanto said that in the process of reconciliation ANBTI always blamed the Muslims, including the Muslim members of FKUB. In additions, Iwan as the head of BKS, in fact blamed Agus in the emerged conflict (I, 2018). The conflict and prejudice has been gone on and on in the complex condition even after the priest has returned home and the church is used accordingly. With this, the conflict is between people in the high level, who are involved in the reconciliation effort. The structural engagement should be the first step to reach the other engagement. However, in the same time, the positive interactions between people in either the same religion or the different religion were intertwined as well. The following passages will explain more about the negative and the positive interactions that were occurred.

\section{b. Between the government and FKUB}

Tomi were criticized and disappointed at FKUB members have been divided by 
religious tendencies. FKUB's condition causes them to be unable to resolve the conflict. Tomi assumes that FKUB has a tendency to take sides with each other's religions when solving inter-religious conflicts. While, the functions of FKUB are to held and organize inter-religious dialogue, which is also means to maintain the harmony of inter-religious relationship; to collect, examine, and convey religious organizations and religious people aspirations into Local Government as recommendation considered to decide the local regulations; to socialize the religious regulations and policies that related with inter-religious relationship and community empowerment; to give written recommendation of house of worship construction (Kemenag, 2017). However, the assistant area as the representation of government FKUB and some parties struggle together to mediate and resolve the GPdI conflict with all the complexity of the case and lack of them.

\section{c. Among religious leaders}

The forming of FKUB Gunungkidul itself was formed in conflict between religious leaders in Gunungkidul. As Iskanto said that according to state regulations, FKUB in each region is made up of five daily administrators, but every religious leader demands equality of authority and all religious leaders demand to involve as the daily administrators. Hence the forming of FKUB was delayed for several years until it was formed in 2011. In contrast, the positive relationship has been occurred in the Diversity School event that was organized by some religious organization (from Islam, Christian, Hinduism, and Buddhism) and FKUB. Those religious organization are BKS (churches organization), Fatayat (youth female organization of Nahdatul Ulama), Forum Lintas Iman (Interfaith Forum), and Buddhism and Hidduism organization in Gunungkidul. The event has targeted youth generation from 15 until 18 years old who are delegated from the involved organizations. The event aim to reduce prejudice from the early ages. The event aims to reduce prejudice from an early age. The event is held two days in three weeks and it only held once for a year. In each week the participants traveled around and stayed in three different houses of worship, as they studied and interacted with people of different faiths and religion, and even different ideology in the same ideologies (I, 2018).

d. Between Muslim and Christian leaders

The prejudice of Christianization by Christian people to Muslims and discrimination by Muslims to Christian people are not only believe by ordinary people, but by the leader also. Here, I will elaborate two cases. First, the case of Christianization in GPdI that has converted some Muslims, which is recognized by Iskanto. According to Iskanto GPdI frequently held charity agendas and medical practices for free in village meeting hall, but there are some circumstances that make people who participate in the agenda and most of they are Muslims, take charity goods from church. The requirement to come to church when the agendas are held has emerged the prejudice. Second, in the case of prejudice of discrimination, one of the conflicts occurred when Christian people has a plan to held the Great Easter in the town square of Gunungkidul. The plan of the Great Easter will invite all of Christian people in Java, to involve celebrate Easter together. In this case, Christian people felt being blocked and complicated to get the permission, until the Christian people looked for the alternative places and the alternative plans. And finally, they held the Great Easter with inviting all Christian people of Gunungkidul held in three churches separately, but still held in the same day and at the same time. In the same time, according to Iskanto, to rival the Great Easter plan, Muslims made a plan to hold the Great Islamic Lecture in the Great Mosque located so close with the twon square of Gunungkidul in the same day at the same time. And at the end, either Muslims or Christians kept held the two great event simultaneously in the different places. (UI, 2018) Moreover, there are some occurrences that Muslims assume as the indicator of Christianization effort, but they cannot provide the accurate data to prove their prejudice or try to understand the reason and the phenomena that was occurred. In fact, for Muslims the actual data is not important and necessary because they base their prejudice with one verse of the Quran that the literal interpretation of the verse legitimize their claim. In contrast, the one of stories about the harmony between Muslims and Christians was represented by Jemari's deed when Muslims execute GPdI priest to be expelled from his house and church. Jemari 
prevent Muslims to do violence to Agus and family, by blocking the road. Another occurrence is the collaboration in organizing Diversity School.

\section{e. Among Christian leaders}

The phenomenon of scramble religious membership among Christian people also occurs among denominations of Christianity. According to Iwan as a head of BKS, he as the Christian priest did not agree with the effort and the way that was done by Agus. He is a GPdI priest. For him, that effort was excessive, so that emerges the suspicious. In additions, he has claimed that if Muslims feel harmed with Agus's deeds, in fact, GKJ (Gereja Kristen Jawa: Christian Church of Java) people that should feel more harmed rather than Muslim side, because the number of GKJ members who are move to GPdI was more than the number of Muslims. However, when conflict occurred and make Agus become victim, Iwan attempt to protect and resolve his problem as best as he can. With this, as fellow Christian person and as fellow Christian priest, Iwan ignore his disagreement. The Iwan's feeling and argument was felt and recognized as well by Kris as GKJ priest, Christian person, and a vice head of FKUB, so that Kris decided and did the same as Iwan has decided and did (I, 2018; K, 2018).

When the conflict was happening, everyone committee to resolve the conflict either, FKUB, NGOs, BKS, or local and regency government, and also attempt to maintain the peace and prevent the conflict after the priest returned home. As the matter of fact, even though everyone has their own tendency and disagreement, even prejudice toward the others, but the humanity, nationalism, and locality encourage them to resolve and help Agus matter. As fellow Indonesia citizen, as fellow human being, and as fellow Javanese, the authority people felt that they as the stakeholders have the responsibility to make Agus return and make church is used accordingly. Their commitment was proved with Agus's return, and moreover with the efforts and agendas held in order to maintain peace and prevent the other conflicts. For instances, the Diversity School, the Harmony Declaration -as an agreement to commit to peace signed by religious leaders in the rest of Gunungkidul-, and some agendas in the inter-religious issues and intra-religious issue.

The negative interactions in structural engagement had been arising because of personal tendency based on theology's reasons, social jealousy and religious interest, leading to prejudice among them. Nevertheless they maintain good communication and relationships that are not based on mutual trust. But more research needs to be done to groups that can build trust between the suspicious intertwined among the community. Because they also come from different religions and groups, but how can they eliminate the inherently theological reasons? Or did the secular reasons that actually have a great effect on the process of awakening prejudice, so that the narrative of religion is only as a tool?

\section{Conclusion}

Inter-religious conflict and its resolution is happen and come true because of many factors. Although many studies have seen the role of grassroots communities as important, the role of community elites, such as religious leaders and local officials, also has an important contribution to make in the occurrence of conflicts and their resolution. This paper wants to bring back the importance of these elite roles. For instance, the leaders build relation, work together, carry out their duties despite suspicion was exist. The suspicion comes with a theological basis, social jealousy, as well as they also can manage conflict to ignore prejudices and the tendency to resolve conflicts based on humanity, nationalism and locality. As a result, those elite people in structural engagement who have the ability to influence enable to make good relationships and trust among them. It is very important to further build the trust among religious people in interreligious relationship.

\section{Bibiography}

A. (2018). Interview.

Banawiratma, J. B. (2010). Dialog Antarumat Beragama: Gagasan dan Praktik di Indonesia. Jakarta: Mizan.

Basri, M. H. (2011). Interreligious Dialogue and the Problem of Truth Claims. Al- 
Ulum: Jurnal Studi Islam, 11(1), 1726.

Campbell, H. (2007). Who's got the power? Religious authority and the Internet. Journal of Computer-Mediated Communication, 12(3), 1043-1062. https://doi.org/10.1111/j.10836101.2007.00362.x

Galtung, J. (1973). Theories of Conflict. Dalam Foreign Affairs.

I. (2018). Interview.

J. (2018). Interview.

Jeong, H. W., \& Michael, E. (2010). Theories Of Conflict. Encyclopedia of Violence, Peace, and Conflict, 21052113. https://doi.org/10.1016/B978012373985-8.00177-X

K. (2018). Interview.

Kemenag. (2017, November 27). Kemenag Akan Perkuat Peran Forum Kerukunan Umat Beragama. Diambil 29 Desember 2021, dari https://kemenag.go.id/read/kemenagakan-perkuat-peran-forumkerukunan-umat-beragama-j3n6j

Kurtz, L. R. (2008). Encyclopedia of Violence, Peace, \& Conflict. Amsterdam: Elsevier. Diambil dari http://www.credoreference.com/book /estpeace

Lattu, I. (2012). Culture and ChristianMuslim Dialogue in MoluccasIndonesia. Interreligious Insight, 4552.
Lattu, I. (2014). Oral and Interrelgious Relationship: The Role of Collective Memory in Christian-Muslim Engagement in Maluku, Indonesia. Berkeley University.

Lattu, I. Y. (2012). Culture and ChristianMuslim Dialogue in MoluccasIndonesia. Interreligious Insight, 10(1), 45-52.

Mubarok, H., Puteri, P. A., Ahsan, R., \& Siragih, J. (t.t.). Is Dialogue Satisfactory for Interreligious Relationship?: A Case of Interreligious Conflict in Gunungkidul, DI Yogyakarta. Yogyakarta.

Regency. (2017). Kabupaten Gunungkidul Dalam Angka Gunungkidul Regency in Figures. Gunungkidul: Badan Pusat Statistik Kabupaten Gunungkidul.

Swidler, L. (2014). Dialogue for Interreligious Understanding; Strategies for the Transformation of Culture-Shaping Institutions (1 ed.). New York: PALGRAVE MACMILLAN.

TH. (2018). Interview.

UI. (2018). Interview. 